UDK $630 * 844.2=111$

UDK $630 * 812.71: 632.4=111$

Original scientific paper

\title{
EFFECTS OF EPYXILOUS FUNGUS Laetiporus sulphureus (Bull. ex Fr.) Murrill ON THE DECCOMPOSITION OF OAK WOOD
}

\author{
Miroslava MARKOVIĆ ${ }^{1}$, Snežana RAJKOVIĆ ${ }^{1}$, \\ Mara TABAKOVIĆ-TOŠIĆ ${ }^{1}$, Marija MILOSAVLJEVIĆ ${ }^{1}$
}

\begin{abstract}
Testing samples were collected from the medulla of healthy oak trees in Eastern Serbia, from the association of Quercetum montanum. Over the periods of 2, 4 and 6 months the wood samples were exposed to influence of the mycelia of the fungus causing cubical brown rot on oak. Given that static modulus of rupture provides the quickest and clearest way to observe destruction caused by epixylous fungi, this paper researched the decrease in modulus of rupture of Sessile oak wood due to influence of causers of cubical brown rot. The samples have been exposed to the impact of the mycelia of the brown rot fungus on oak tree Laetiporus sulphureus (Bull. ex Fr.) Murrill (Sulphur Polypore). Effect of to the impact of the brown rot fungi was investigated, in decrease of static modulus of rupture Quercus petraea agg. The static modulus of rupture caused by L. sulphureus after 2, 4 and 6 months decreased in comparison with initial ones (100\%) and reached 91.73, 75.17 and $63.25 \%$. By using correlation analyses of $Q$. petraea agg. static modulus of rupture - $\sigma_{s}$ (dependent variable) of fungi time influence (T-independent variable) strong correlation between variables was established, and regression equation is:
\end{abstract}

$$
\sigma_{\mathrm{s}}=151.514 \pm 30,657 \sqrt{\mathrm{T}}
$$

The regression line obtained through data processing opened the possibility to prognosticate the changes of wood properties in certain time periods of the effect of the

\footnotetext{
1 Autor za kontakt: Dr Miroslava Marković, naučni saradnik, Institut za šumarstvo, Beograd, tel. +381691999116, Email: mira013@gmail.com

Dr Snežana Rajković, naučni savetnik, Institut za šumarstvo, Beograd, Dr Mara Tabaković-Tošić, naučni savetnik, Marija Milosavljević, Master, istraživač saradnik

Acknowledgment: The study was carried out within the Project TR 31070 "The development of technological procedures in forestry with a view to an optimum forest realization", financed by the Ministry of Education, Science and Technological Development of the Republic of Serbia (2010-2017).
} 
fungus under the unchanged external conditions, which is significant for practical purposes in terms of taking protective measures and wood usability.

Key words: Laetiporus sulphureus, Modulus of rupture

\section{DEJSTVO EPIKSILNE GLJIVE Laetiporus sulphureus (Bull. ex Fr.) Murrill NA DEKOMPOZICIJU HRASTOVOG DRVETA}

Izvod: Uzorci za ispitivanje su prikupljeni iz srčike zdravog drveta hrasta u istočnoj Srbiji, iz asocijacije Quercetum montanum. Tokom perioda od 2, 4 i 6 meseci uzorci drveta su izloženi uticaju micelije gljive koja prouzrokuje mrku prizmatičnu trulež. S obzirom da statička čvrstoća na savijanje daje najbrži i najjasniji način za posmatraje destrukcije drvne mase izazvane epiksilnim gljivama, $u$ ovom radu ispitivano je smanjenje čvrstoće na savijanje drveta dejstvom uzročnika truleži. Uzorci su izloženi uticaju micelije gljive Laetiporus sulphureus (Bull. ex Fr.) Murrill (sumpornjača) na drvetu Quercus petraea agg. Statička čvrstoća na savijanje pod dejstvom L. sulphureus posle 2, 4 i 6 meseci smanjena je u poređenju sa početnom (100\%) $i$ iznosila 91.73, 75.17 i 63.25\%. Korišćenjem korelacione analize $Q$. petraea agg. statičke čvrstoće na savijanje $\sigma_{s}$ (zavisna varijabla) u vremenu dejstva gljive (T-nezavisna varijabla), utvrđena je jaka korelaciona veza između varijabli, a regresiona jednačina statičke čvrstoće na savijanje iznosi:

$$
\sigma \mathrm{s}=151.514 \pm 30,657 \sqrt{\mathrm{T}}
$$

Regresiona linija dobijena obradom podataka otvorila je mogućnost prognoziranja promene svojstava drveta $u$ određenom vremenskom periodu dejstva gljive, pod nepromenjenim uslovima spoljne sredine, što je značajno za praktičnu primenu, u smislu preduzimanja mera zaštite i upotrebljivosti drveta.

Ključne reči: Laetiporus sulphureus, čvrstoća na savijanje

\section{INTRODUCTION}

Development of the wood processing industry is causing growing demand for high-quality wood raw materials $[14,18]$. This calls for preservation and extension of wood durability, which is directly linked to preservation of physical, chemical, mechanical, aesthetical and other properties, according to several authors $[7,8,15,21]$. Basic structural constituents of wood (cellulose, hemicellulose and lignin) are distributed in different percentages in different species and parts of trees. There is thus more cellulose in soft than hard species of trees, in bolewood more than in branchwood, in early successional species more than in late ones, as discussed by Miric and Popovic [16].

Oak as a host is colonized by a large number of microorganisms, where a special place belongs to the research on impact of fungi, particularly those attacking the core (srcika) as the technically most valuable part of a tree $[1,3,4]$. Through its enzyme system, the epixylous fungi break down the constituents of wood cell walls, modify the percentage of their participation and thus directly induce changes of the wood properties $[2,6,11]$. The agents of brown prismatic rot (to which the researched fungus $L$. sulphureus belongs) disintegrate primarily cellulose, while the disintegration of lignin occurs in a far smaller extent. 
This paper presents the course of alteration (decrease) of the presence of lignin in the cell wall, reflected in the decrease of wood bulk modulus of $Q$. petraea agg. under the influence of the fungus L. sulphureus after 2, 4 and 6 months of the incubation $[26,20,17]$.

\section{MATERIAL AND METHODS}

The substrate used in the research was a 110-year-old healthy tree of Sessile oak $Q$. petraea agg., $19 \mathrm{~m}$ tall and $35 \mathrm{~cm}$ in diameter at breast height. The tree had been cut in Eastern Serbia, at the altitude of $550 \mathrm{~m}$, on the southern exposition and in association Quercetum montanum [25]. The analyses were conducted on a $\log 3.5 \mathrm{~m}$ in length (from the lower part of the trunk to the first live branch), which was according to the relevant pattern cut into specimens using the standard prescribed dimensions $2 \times 2 \times 32 \mathrm{~cm}$. The fronts of specimens were smeared with antiseptic paste so as to prevent penetration of hyphae from that direction, given the small dimensions of the specimens representing a large beam used for practical purposes. Since the development of cross-section hyphae is the fastest, if the penetration of hyphae was enabled from that side, the small specimens would quickly rot and the relevant results would not be obtained.

The specimens were dried in a classic drying chamber at the temperature of $103 \pm 1{ }^{\circ} \mathrm{C}$ and measured with the accuracy of $0.01 \mathrm{~g}$. On control specimens (healthy wood), the modulus of elasticity was measured on universal machine for testing wood properties $[23,24]$. The specimens to be exposed to the mycelia were conditioned at approximately $12 \%$ humidity. Mycelia L. sulphureus was resown into plastic Petri dishes containing malt-agar growing medium of standard concentration. The experiment used sterilized plastic vessels with lids into which Petri dishes with fully developed mycelia $L$. sulphureus were placed. The petri dishes served as glass carriers (dimensions $9 \times 22 \times 35 \mathrm{~cm}$ ) in order to prevent excessive soaking of moisture from the growing medium, onto which wood specimens of Sessile oak were placed. On the top of the stack were petri dishes with 5\% water solution of boric acid intended to induce high relative air humidity.

By definition, modulus of rupture is the resistance of a tree to the effect of concentrated, evenly distributed or combined forces that strive to bend or distort it. Therefore, the bending pressure is a complex strain consisting of a thrust pressure in the part of the carrier closer to the action point and the strain pressure at the opposite side. Between these two zones there is a neutral axe which under the impact of the load moves towards the side of the strain pressure [22]. Given that the flexural strength is calculated relative to the cross section of a tree at the point of effect of the force, before measuring the strength all test tubes were measured across the middle using a micrometer, with the accuracy of $0.01 \mathrm{~mm}$. The distance between braces was $280 \mathrm{~mm}$, while the test tubes were exposed to the action of a single concentrated force in the middle of the distance between braces. All data obtained were processed by applying the standard statistical methods; destruction results were compared using the single factor analysis of variance and the least significant difference test for the control group and the duration of the fungus impact (2, 4 and 6 months). 
Statistical data processing was done on absolute amounts - N/mm $\mathrm{m}^{2}$, while a correlation analysis was performed in order to prove the existence of a link between the time of action of the fungus as the independent variable and change of modulus of rupture as the dependent variable.

\section{RESULTS AND DISCUSSION}

During the course of their development, the epixilous fungi feeding on basic constitutional components of the tree alter not only its chemical composition but also its entire inner structure, which results in a change, i.e. decrease in its mechanical, physical, aesthetical and other properties. Brown rot agents in wood cause analogous chemical changes created during the hydrolysis of the tree by mild acids [20]. Through metabolic processes, fungi modify the nutritious matter down to the molecules suitable to their own life functions.

In order to analyze the changes of wood properties under the influence of epixilous fungi, it is necessary to provide a brief explanation of the fungi's need for nutrients, chemical composition of the tree, as well as changes that occur in the chemical composition and tree structure under their influence. All wood-decay fungi are able to use finished products such as free sugars, lipids, peptides and other primary metabolites. These substances have a crucial impact in the initial phase of tree colonization. Carbohydrates are the most significant source of carbon in nutrition of the epixilous fungi. A rich source of carbon lies in the basic structural elements of the wood cell walls (hemicellulose, cellulose and lignin). Cellulose, which is the most widely present element on earth, builds the skeletal substance of the cell wall and represents the most important constituent of wood [9, $12]$.

Dissolution of cellulose does not occur evenly throughout the affected tree, since hyphae are individual and unorganized. Thus only a few cells are attacked at first, but their number gradually rises [13]. Moreover, dissolution of cellulose goes quickly at first and later on slows down, which is a consequence of the effect of the fungus that first demolishes the free cellulose in the middle layer of the secondary wall, given that this layer has virtually no impregnation with lignin. As soon as the fungus gets into the parts of cellular membrane with a higher lignin content, the dissolution slows down, so that the dissolution of cellulose in the primary wall is the slowest, as this is where the largest portion of total lignin is incorporated [5]. Changes of the tree structure are reflected primarily in the modulus of elasticity, with the process being roughly 2 to 3 times faster in brown rot agents. Basic parameters of the modulus of elasticity of $Q$. petraea agg. samples that were exposed to the effect of the species $L$. sulphureus for 2, 4 and 6 months compared to the control are presented in table 1 and expressed in absolute values. 
Table 1. Modulus of rupture reduction (\%) under the influence of the L. sulphureus

\begin{tabular}{||l||c|c|c|c||}
\hline & $\begin{array}{c}0 \\
\text { months }\end{array}$ & $\begin{array}{c}2 \\
\text { months }\end{array}$ & $\begin{array}{c}4 \\
\text { months }\end{array}$ & $\begin{array}{c}6 \\
\text { months }\end{array}$ \\
\hline \hline Number of measurements & 30 & 30 & 30 & 30 \\
\hline Minimum amount & 109.74 & 75.87 & 34.24 & 16.42 \\
\hline Maximum amount & 205.98 & 206.97 & 179.49 & 156.79 \\
\hline Arithmetic mean & 156.12 & 143.21 & 117.35 & 98.75 \\
\hline Standard deviation & 28.65 & 29.34 & 40.62 & 36.32 \\
\hline Variation coefficient & 18.35 & 20.49 & 34.62 & 36.78 \\
\hline
\end{tabular}

The table 1 demonstrates that the smallest dissipation of data (variation coefficient) occurs in the control group of samples (18.35), while the highest is after 2 and 6 months of exposure to the species L. sulphureus (20.49 and 36.78), which is a consequence of non-homogenous tree structure and uneven colonization of the tree by the fungus. The average modulus of elasticity amounts to 156.12 in the control group of samples, 143.21after 2 months of exposure to fungus $L$. sulphureus, 117.35 after 4 months, and $98.75 \mathrm{~N} / \mathrm{mm}^{2}$ after 6 months of exposure.

Therefore, the greatest decrease of the modulus of elasticity of $Q$. petraea agg. exposed to the fungus $L$. sulphureus occurs during the first 2 months, after which the process slows down. According to Rayner and Boddy [20], changes of tree properties under the influence of most brown rot agents are primarily reflected in changes of the modulus of elasticity and occur immediately following the appearance of first signs of rot, which is in this case particularly evident. Based on results of T- test, shown in table 2 , it is clear that significant differences occur as early as first 2 months of the influence of the fungus L. sulphureus and apply to all tested sample groups, except for the period between months 2 and 4 .

Table 2. Modulus of rupture reduction under the influence of $L$. sulphureus

\begin{tabular}{||l||c|c|c|c||}
\multicolumn{5}{|c|}{ (T test) } \\
\hline \hline 0 months & 0 months & 2 months & 4 months & 6 months \\
\hline 2 months & - & 12.9138 & 38.7752 & 57.3717 \\
\hline 4 months & & - & 25.8614 & 44.4579 \\
\hline 6 months & & & - & 18.5965 \\
\hline \hline
\end{tabular}

- Significant difference at the level of 0.05

This means that over this period there is no significant loss of the modulus of elasticity, with the differences being only the consequence of high variability of data, not exposure to the fungus. Based on the analysis of breakages of test tubes of Sessile oak exposed to L. sulphureus during the process of measuring the modulus of rupture, it was found that in the first 2 months a large number of test tubes had smooth breakages in addition to short-fiber ones. Kruzsik [10] states that a tree with a higher modulus of elasticity has a long-fiber breakage, with a medium modulus short-fiber breakage, and with a low modulus a smooth breakage. 
Table 3. Correlation analysis of exposure time to fungus

L. sulphureus and wood properties

\begin{tabular}{|c|c|c|c|}
\hline Tested property & Model type & $\begin{array}{c}\text { Correlation } \\
\text { coefficient }(\mathrm{r})\end{array}$ & Regression equation \\
\hline $\begin{array}{c}\text { Modulus of } \\
\text { elasticity } \\
\left(\sigma_{\mathrm{s}}\right)\end{array}$ & $\begin{array}{c}\text { Square function } \\
(\mathrm{x})\end{array}$ & \pm 0.992802 & $\sigma_{\mathrm{s}}=151.514 \pm 30.657 \sqrt{\mathrm{T}}$ \\
\hline
\end{tabular}

The obtained results lead to conclusion that after 6 months of exposure to the fungus the process of destruction of the tree, although highly advanced, is probably not completed, meaning that there is a possibility that the cell membrane layers may still contain the sufficient quantity of cellulose that provides the modulus of rupture. Correlation analysis was performed in order to establish a correlation link between the tested tree properties depending on the time of exposure to the fungus (Tab. 3).

This is significant for the purposes of practical application, i.e. for protection measures and wood utility. According to literature sources $[18,20]$ this property represents the quickest and clearest indication of destruction under the influence of epixilous fungi. To this effect, appropriate chemical analyses of wood exposed to influence of fungi could provide a clearer definition from both qualitative and quantitative aspect, allowing a comprehensive insight into the course and consequences of development of fungi in trees.

\section{CONCLUSIONS}

After 2, 4 and 6 months under the effect of the fungus $L$. sulphureus, the modulus of rupture of oak wood substantially decreased compared to the initial value $(100 \%)$ and amounted to $91.73 \%, 75.71 \%$ and $63.25 \%$ respectively. In the period between 2 and 4 months the process of destruction slowed down and the loss amounted to only $16.02 \%$. In the period between the months 4 and 6 the destruction mildly rose and the modulus of rupture dropped by another $39.46 \%$.

Correlation analysis showed a strong correlation link between the changes (decrease) in wood properties of $Q$. petraea agg. and the time of the influence of the fungus $L$. sulphureus. This opens the possibility to use the regression equation in forecasting modifications in wood properties, depending on the time of exposure to a fungus, under unchanged environmental conditions.

If a future research would carry out similar experiments on our most significant tree species against the greatest and most dangerous wood destructors, over a larger number of monitoring periods, the obtained results could serve as basis for creation of relevant tables (standards). By cross-referencing the obtained data and conducting their statistical analysis, we would arrive at the closest approximation of values to be inserted into relevant tables and applied in practice. 


\section{REFERENCES}

[1] Brown MA, Zhao Z, Mauk AG (2002): Expression and characterization of a recombinant multi-copper oxidase: laccase IV from T. versicolor. Inorg Chim Acta; 331: 232-238.

[2] Chu KKW, SS Ho and AH Chow (2002): C. versicolor: a medicinal mushroom with promising immunotherapeutic values, Journal of Clinical Pharmacology, 42: 967-984

[3] Darrel DN (1985): Wood deterioration and its Prevention by preserve Treatments, University Press, Syracuse, New York, p 381

[4] David OM, Fagbohun ED, Oluyege AO and Adegbuyi A (2012): Antimicrobial activity and physicochemical properties of oils from tropical macrofungi, Journal of Yeast and Fungal Research Vol. 3(1), pp. 1-6

[5] Jankovský L, Vágner A, Apltauer J (2002): The decomposition of wood mass under conditions of climax spruce stands and related mycoflora in the Krkonose Mountains, Journal of Forest Science, 48 (2): 70-79

[6] Karadzic D and Andjelic M (2002): The most common wood decay fungi in forests and wood repositories, Monograph, Montenegrian Center for Forest Improvements, Podgorica, 120 - 154 pp [In Serbian].

[7] Karadzic, D (2006): "Influence of the parasitic fungi on the health condition of the Sessile oak, Hungarian oak and Turkey oak trees in natural forests and urban areas", Forestry, July - October, pp. 47-60

[8] D. Karadzic, D (2010): "Forest Phytopathology", Belgrade, Planet Print, p. 774

[9] Knezevic, M (1975):“Mechanical wood processing”. Construction Book, Belgrade, p. 184

[10] Krzusik, F (1974): "Nauka o drevnie", Warszawa

[11] Lee S, Bae H, Kim N, Hwang S (2008): Optimization of Growth Conditions of Lentinus edodes Mycelium on Corn Processing Waste Using Response Surface Analysis, J. Biosci. Bioeng. Soc. Biotechnol Jap., 105(2): 161-163.

[12] Markovic, M, Rajkovic, S, Miric, M, Mitic, D, Milovanovic, J, Tabakovic-Tosic, M (2011a): "Colonization of the substrate of wood - decaying fungi Fomitopsis pinicola (Sw.:Fr.) P. Karst. isolated from beech and fir under controlled temperature and $\mathrm{pH}$ conditions", Fresenius Environmental Bulletin, vol 20, no 3, pp. 583-589, 2011.

[13] Markovic, M, Rajkovic, S, Miric, M, Mitic, D, Rakonjac, Lj (2011b): “Growth conditions of mycelium medicinal mushroom Lentinula edodes (Berk.) Pegl. in the substrate colonization phase", Scientific Research and Essays, 8 September, vol 6 (19), pp. 4133-4140

[14] Miric, M, Schmidt, O (1992): "Nutrition some stereoid mushrooms", Journal of Faculty of Forestry, No. 74th, University of Belgrade, Belgrade, pp. 111 - 115

[15] Miric, M (1993): The most important bio-ecological studies of fungi in the genus Stereum, challenger rot of oak wood, Ph.D. Thesis, Faculty of Forestry, Belgrade, pp. 120 [In Serbian]. 
[16] Miric M, Popovic Z (1993): Influence of Pleurotus ostreatus (Jacq.) Fr. and Trametes versicolor (L. ex Fr.) Pilat. the loss of hardness, compressive strength and mass of beech wood, Lumber Bulletin No. 6-7, Belgrade, pp 36-40 [In Serbian].

[17] Miric M (2005): Impact of stereoide fungi on decomposition of oak wood and possibility of its protection. Bulletin of the Faculty of Forestry, Issue 91, pp 31-61 [In Serbian].

[18] Miric, M, Ivkovic, S, Rajkovic, S, Markovic, M (2012): "Microscopical changing of the main Wood anatomical elements of Pedunculate and Sessile Oaks due to attack of the White rot fungus Chondrostereum purpureum (Pers. ex Fr.) Pouz.", Fresenius Environmental Bulletin, vol. 21, no 1, pp. 26-30

[19] Petrovic M (1980): Protection of wood 2 , Scientific Book, Belgrade, p 440 [In Serbian].

[20] Rayner ADM, Boddy, L (1998): Fungal decomposition of Wood, Its Biology and Ecology, A Willey - Interscience Publication, Avon

[21] Schmidt O (1994): Holz und Baumpilze, Biologie, Shaden, Schutz, Nutzen, Springer Verlaf. Berlin - Heidelberg, pp 48

[22] Soskic, B (1994): "Wood Properties", Book of Faculty of Forestry, University of Belgrade, Belgrade [In Serbian]

[23] SRPS D.A1.040:1979: “Testing of the wood, Taking specimens ISS" [In Serbian]

[24] SRPS D.A1.058: "Protection of the wood, Test for resistance to the fungus", (Official Gazette No. 36/09: Ordinance on the technical and other requirements in the forestry and wood processing industry) [In Serbian].

[25] Tomic, Z (1992): "Forest phytocenoses in Serbia" ["Sumske fitocenoze u Srbiji"], Book of Faculty of Forestry, Belgrade, pp. 26

[26] Vucetic J (1998): Microbiological synthesis of antibiotics, the First Part of a General, Second Revised Edition, Velarta, Belgrade, p 168 [In Serbian] 


\title{
EFFECTS OF EPYXILOUS FUNGUS Laetiporus sulphureus (Bull. ex Fr.) Murrill ON THE DECCOMPOSITION OF OAK WOOD
}

\author{
Miroslava MARKOVIĆ, Snežana RAJKOVIĆ, \\ Mara TABAKOVIĆ-TOŠIĆ, Marija MILOSAVLJEVIĆ
}

\begin{abstract}
Summary
Testing samples were collected from the medulla of healthy oak trees in Eastern Serbia, from the association of Quercetum montanum. Over the periods of 2, 4 and 6 months the wood samples were exposed to influence of the mycelia of the fungus causing cubical brown rot on oak. Given that static modulus of rupture provides the quickest and clearest way to observe destruction caused by epyxilous fungi, this paper researched the decrease in modulus of rupture of Sessile oak wood due to influence of causers of cubical brown rot. The samples have been exposed to the impact of the mycelia of the brown rot fungus on oak tree Laetiporus sulphureus (Bull. ex Fr.) Murrill (Sulphur Polypore). Effect of to the impact of the brown rot fungi was investigated, in decrease of static modulus of rupture Quercus petraea agg. The static modulus of rupture caused by L. sulphureus after 2, 4 and 6 months decreased in comparison with initial ones (100\%) and reached 91.73, 75.17 and $63.25 \%$. Dissolution of cellulose does not occur evenly throughout the affected tree, since hyphae are individual and unorganized. Thus only a few cells are attacked at first, but their number gradually rises. Changes of the tree structure are reflected primarily in the modulus of elasticity, with the process being roughly 2 to 3 times faster in brown rot agents. Over this period there is no significant loss of the modulus of elasticity, with the differences being only the consequence of high variability of data, not exposure to the fungus. Based on the analysis of breakages of test tubes of Sessile oak exposed to L. sulphureus during the process of measuring the modulus of rupture, it was found that in the first 2 months a large number of test tubes had smooth breakages. The obtained results lead to conclusion that after 6 months of exposure to the fungus the process of destruction of the tree, although highly advanced, is probably not completed, meaning that there is a possibility that the cell membrane layers may still contain the sufficient quantity of cellulose that provides the modulus of rupture. Correlation analysis was performed in order to establish a correlation link between the tested tree properties depending on the time of exposure to the fungus. This is significant for the purposes of practical application, i.e. for protection measures and wood utility. To this effect, appropriate chemical analyses of wood exposed to influence of fungi could provide a clearer definition from both qualitative and quantitative aspect, allowing a comprehensive insight into the course and consequences of development of fungi in trees.
\end{abstract}




\title{
DEJSTVO EPIKSILNE GLJIVE Laetiporus sulphureus (Bull. ex Fr.) Murrill NA DEKOMPOZICIJU HRASTOVOG DRVETA
}

\author{
Miroslava MARKOVIĆ, Snežana RAJKOVIĆ, \\ Mara TABAKOVIĆ-TOŠIĆ, Marija MILOSAVLJEVIĆ
}

\section{Rezime}

Uzorci za ispitivanje su prikupljeni iz srčike zdravog drveta hrasta u istočnoj Srbiji, iz asocijacije Quercetum montanum. Tokom perioda od 2, 4 i 6 meseci uzorci drveta su izloženi uticaju micelije gljive koja prouzrokuje mrku prizmatičnu trulež. S obzirom da statička čvrstoća na savijanje daje najbrži i najjasniji način za posmatraje destrukcije drvne mase izazvane epiksilnim gljivama, u ovom radu ispitivano je smanjenje čvrstoće na savijanje drveta dejstvom uzročnika truleži. Uzorci su izloženi uticaju micelije gljive Laetiporus sulphureus (Bull. ex Fr.) Murrill (sumpornjača) na drvetu Quercus petraea agg. Statička čvrstoća na savijanje pod dejstvom $L$. sulphureus posle 2, 4 i 6 meseci smanjena je u poređenju sa početnom (100\%) i iznosila 91.73, 75.17 i 63.25\%. Razlaganje celuloze ne javlja se podjednako u celom napadnutom drvetu, jer su hife individualne i neorganizovane. Prema tome, samo nekoliko ćelija su napadnute u početku, ali njihov broj postepeno raste. Promene u strukturi drveta se ogledaju pre svega u čvrstoći na savijanje, gde je proces oko 2 do 3 puta brži kod prouzkovača mrke prizmatične truleži. Na osnovu analize lomova na epruvetama kitnjaka izloženih dejstvu gljive L. sulphureus tokom procesa ispitivanja čvrstoće na savijanje, utvrđeno je da je u prva 2 meseca veliki broj epruveta imao glatke lomove. Dobijeni rezultati upućuju na zaključak da je nakon 6 meseci izlaganja truležnici, proces destrukcije drveta, mada je vrlo napredovao, verovatno nije završen, što znači da postoji mogućnost da slojevi ćelijske membrane i dalje sadrže dovoljnu količinu celuloze koja obezbeđuje čvrstoću na savijanje. Korelaciona analiza je urađena u cilju uspostavljanja korelacije veza između svojstava testiranog drveta u zavisnosti od vremena dejstva gljive. Ovo je značajno za praktičnu primenu, odnosno mere zaštite drveta i njegovu upotrebljivost. U tom smislu, odgovarajuće hemijske analize drveta izloženog uticaju gljiva može pružiti jasniju definiciju kroz kvalitativne i kvantitativne aspekte, omogućavajući sveobuhvatan uvid o toku i posledicama razvoja gljiva na drvetu. 